\title{
Spatial and temporal variations of oxygen isotopes in snowpacks and glacial runoff in different types of glacial area in western China
}

\author{
Yuanqing HE, ${ }^{1}$ Hongxi PANG, ${ }^{1}$ W.H. THEAKSTONE, ${ }^{2}$ Dian ZHANG, ${ }^{3}$ Aigang LU, ${ }^{1}$ \\ Bo SONG, ${ }^{1}$ Lingling YUAN, ${ }^{1}$ Baoying $\mathrm{NING}^{1}$ \\ ${ }^{1}$ Cold and Arid Regions Environmental and Engineering Research Institute, Chinese Academy of Sciences, \\ 260 Donggang West Road, Lanzhou 730000, China \\ ${ }^{2}$ School of Environment and Development, University of Manchester, Oxford Road, Manchester M13 9PL, UK \\ ${ }^{3}$ Department of Geography, University of Hong Kong, Pokfulam Road, Hong Kong
}

\begin{abstract}
In order to improve understanding of spatial and temporal variations of stable isotopes in atmospheric precipitation, snow cover and glacier meltwater in different regions of China, samples were collected for isotopic analysis in four areas: Yulong mountain, Yunnan Himalaya (temperate-glacier area); Samdain Kangsang mountain, Nyainqêntanglha Shan (subpolar-glacier area); the headwater area of the Ürümqi river, Tien Shan (subpolar-glacier area); and Muztag mountain, Pamirs (polar-glacier area). Sampling was undertaken in both summer and winter between 2000 and 2003. The $\delta^{18} O$ values show a 'temperature-altitude effect' in new winter snow on Yulong mountain, reflecting the condensation and fractionation processes associated with the winter monsoon, but a different, more complex pattern in residual snow deposited during the summer monsoon; this old snow is influenced by the 'precipitation amount effect', solar radiation and evaporation, and the water content of the snowpack. The summer precipitation at Samdain Kangsang mountain is associated with the summer monsoon. There is a marked precipitation amount effect during the long passage of the southwest/India monsoon from the distant moisture source to Samdain Kangsang mountain, and the summer precipitation is strongly depleted of the heavy isotope. Above $6000 \mathrm{~m}$, the high radiation flux causes much evaporation from the snow surface. The associated ${ }^{18} \mathrm{O}$ enrichment of the snow is reflected in a 'reverse altitude effect'. The $\delta^{18} \mathrm{O}$ values in the summer snowpack of the Tien Shan and Muztag mountain decrease with increasing altitude and decreasing air temperature, indicating a temperature-altitude effect. Post-depositional processes cause isotopic changes during the transformation of snow/firn/ice to meltwater; the effects are much stronger at temperate than at polar glaciers. Moreover, changes in the isotopic signal at both temperate and polar glaciers can result from evaporation, sublimation, ablation and drifting.
\end{abstract}

\section{INTRODUCTION}

Glaciologists, climatologists and hydrologists are interested in using stable isotopes and environmental chemistry as indicators of the processes involved in atmospheric precipitation, the transformation of snow to ice, and runoff from glaciers (Dansgaard, 1964; Moser and Stichler, 1980; Theakstone, 1988, 2003; Wagenbach, 1989; He and Theakstone, 1994; Raben and Theakstone, 1998; Theakstone and Knudsen, 1989, 1996; He and others, 2001a, b). Studies at high-altitude sites have expanded knowledge of the links between climate and the isotopic composition of precipitation (Niewodniczaéski and others, 1981; Grootes and others, 1989; Thompson and others, 1998; Stichler and others, 2001; Bradley and others, 2003). Since the early 1990s, scientists in China have used stable isotopes to study the distribution of atmospheric precipitation and the features of the water cycle on the Tibetan Plateau (Zhang and Yao, 1995; Tian and others, 1997, 2001, 2003; He and others, 2001a; Zhang and others, 2001) and have considered vapor sources as an important factor impacting the distribution of oxygen isotopes in precipitation.

Under the influence of continental air masses, $\delta^{18} \mathrm{O}$ values of precipitation on the Tibetan Plateau are related to temperature, the so-called 'temperature effect', also termed the 'altitude effect' because temperature decreases with increasing altitude (Ingraham, 1998). However, especially in monsoon-climate regions, where fractionation is related to the intensity of the convective process, which is approximately proportional to the amount of precipitation, a negative correlation between $\delta^{18} \mathrm{O}$ values and the precipitation amount/temperature, the 'precipitation amount effect', has been noted (Johnson and Ingram, 2004). Isotopic fractionation in the snow cover during the transformation of snow to ice to meltwater may change the 'temperature/ altitude effect' into a 'reverse altitude effect'.

The uplift of the Tibetan Plateau has resulted in a complex climatic situation in China (Shi and others, 1988, 2000). Dependent upon the direction of approach of vapor sources, the westerly circulation or the south Asia monsoon circulation, which can be divided into the southwest and southeast monsoons, prevails in western China (Fig. 1).

Shi and Xie (1964) classified China's glaciers into the marine type (akin to temperate glaciers elsewhere) and the continental type (termed polar glaciers elsewhere), and subdivided the latter into subpolar and polar glaciers according to the climate conditions and associated physical properties during their formation. The temperate glaciers described here are controlled principally by maritime air masses, but the polar glaciers are influenced by continental air masses with markedly different chemical and physical characteristics (Su and Li, 1996; Tian and others, 2001). Figure 1 shows the different glacial areas in western China. 


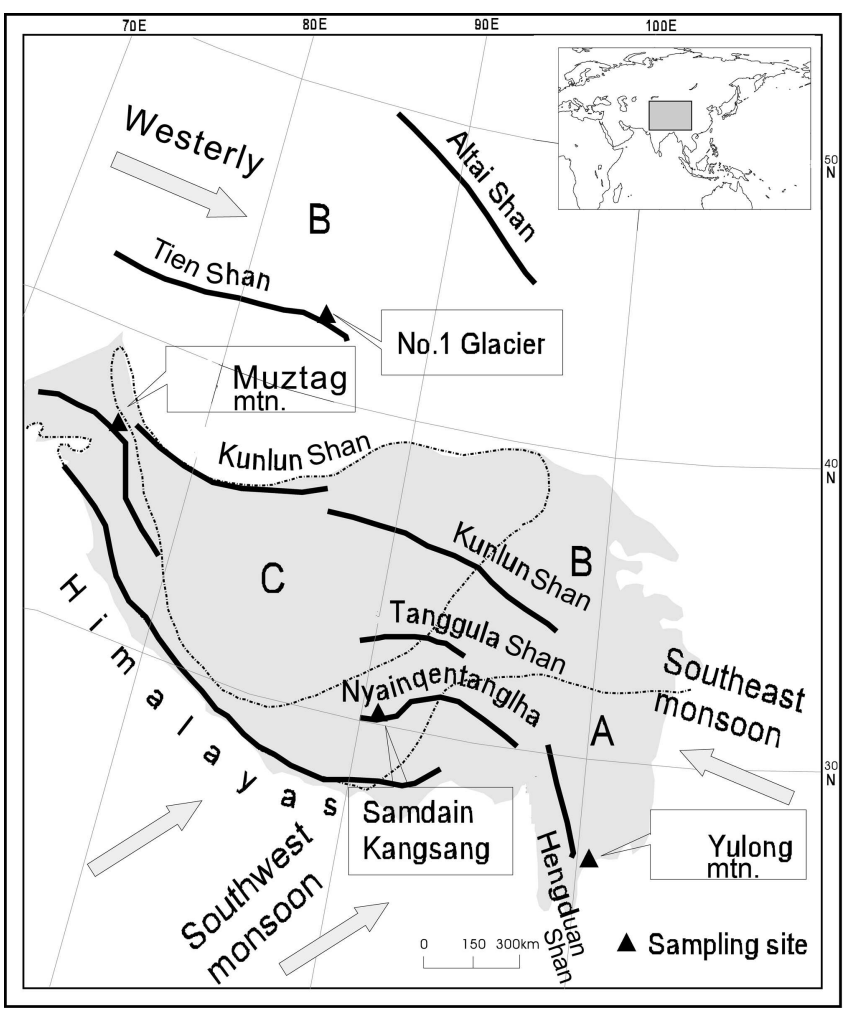

Fig. 1. Sampling sites and areas with different types of glacier in western China: A. temperate-glacier area; B. subpolar-glacier area; C. polar-glacier area.

In order to compare the temporal and spatial distributions of stable isotopes in the system which relates atmospheric precipitation, accumulated snow, glaciers and meltwater runoff, and to elucidate the changes in isotopic ratios during melting and phase-change processes in snow and ice, systematic sampling of snow and snow/ice meltwater was carried out on Yulong mountain, Yunnan Himalaya (temperate-glacier area); Samdain Kangsang mountain, Nyainqêntanglha Shan (subpolar-glacier area); the headwater area of the Ürümqi river, Tien Shan (subpolar-glacier area); and Muztag mountain, Pamirs (polar-glacier area) (Fig. 1). Sampling was undertaken at different elevations and in different seasons (summer and winter) from 2000 until 2003. Logistical constraints limited the number of samples that could be collected at the remote, high-altitude sites. Here, the results of oxygen isotope analysis of the samples are presented to provide a better understanding of the spatial and temporal variations observed in snow and snow meltwater from four glaciers in western China.

\section{THE STUDY AREAS, FIELD SAMPLING AND LABORATORY ANALYSIS}

Yulong mountain $\left(27^{\circ} 10^{\prime} \mathrm{N}, 100^{\circ} 15^{\prime} \mathrm{E}\right)$, located at the south end of the Hengduan Shan, $25 \mathrm{~km}$ north of Lijiang, Yunnan Province, is the southernmost glacier-covered mountain in China (Fig. 1). With a highest peak of $5596 \mathrm{~m}$, it is closer to the Equator than any other glacierized area in mainland Eurasia. Its climate, dominated by the southwest monsoon from the Indian Ocean, is characterized by warm, wet summers and cold, dry winters, with an annual precipitation of 1000-2000 mm. The 19 glaciers on Yulong mountain are typical temperate glaciers. The largest, Baishui glacier No. 1

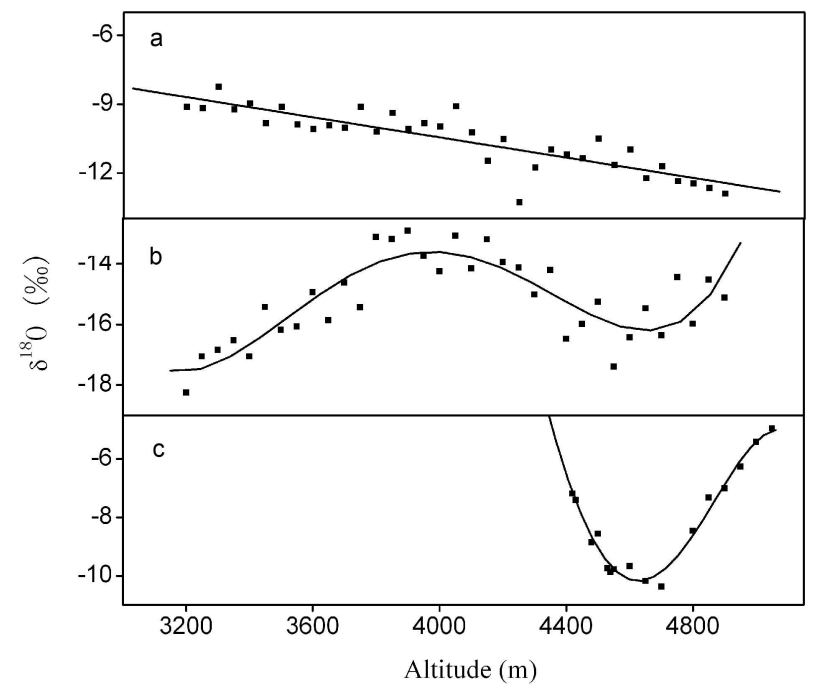

Fig. 2. (a) Variation of $\delta^{18} \mathrm{O}$ values with altitude in the new snowpack at Yulong mountain, 26 November 2002. (b) Variation of $\delta^{18} \mathrm{O}$ values with altitude in the melting residual snowpack at Yulong mountain, 15 November 2002. (c) Variation of $\delta^{18} \mathrm{O}$ values with altitude in the melting snowpack at Yulong mountain, July 2000.

(BG1), is located on the eastern slope. It extends from $>5000$ to $4100 \mathrm{~m}$ a.s.I., with an equilibrium-line altitude (ELA) of $4800 \mathrm{~m}$. Samples of melting residual snow, and ice and snow meltwater were collected at the glacier in July 2000. In November 2002, samples of newly deposited snow also were collected. Samples were taken at intervals of 50-100 m between 3200 and 5000 ma.s.I. Samples of old (residual) snow which had fallen between late October and early November were collected on 15 November 2002, and samples of newly deposited snow were collected on 26 November 2002, when the summer monsoon had ended and the winter-monsoon precipitation produced by continental air masses had begun.

Samdain Kangsang mountain $\left(30^{\circ} 54^{\prime} \mathrm{N}, 91^{\circ} 30^{\prime} \mathrm{E}\right)$, with a highest peak of $6590 \mathrm{~m}$, is located in the western section of the Nyainqêntanglha Shan in Naqu, Tibet. Although affected by the southwest monsoon climate, it is a subpolar glacier area, with an annual precipitation of $400-500 \mathrm{~mm}$. In August 2003, samples of new snow were collected at a height interval of $100 \mathrm{~m}$ between 5500 and $6700 \mathrm{~m}$ a.s.l.

The headwaters of the Ürümqi river, in the eastern section of the Tien Shan $\left(43^{\circ} 04^{\prime} \mathrm{N}, 86^{\circ} 30^{\prime} \mathrm{E}\right)$, are influenced in part by the westerly circulation, with moisture from the Atlantic Ocean and Mediterranean Sea reaching the area. More than $3000 \mathrm{~km}$ from the nearest sea, it is a subpolar glacier area, controlled by a semi-arid interior climate, with an annual precipitation of 400-600 mm. Ürümqi glacier No. 1 (UG1) is located between 3800 and $4300 \mathrm{~m}$ a.s.l., and its ELA is at approximately $4050 \mathrm{~m}$. The glacier has two branches. In July and August 2002, samples of newly deposited snow were collected between 3800 and 4200 ma.s.I. on the western branch, and samples of melting residual snow were collected within the same altitudinal range on the eastern branch.

Muztag mountain, situated in the eastern part of the Pamirs $\left(38^{\circ} 14^{\prime} \mathrm{N}, 75^{\circ} 03^{\prime} \mathrm{E}\right)$ with an arid interior climate, is a polar-glacier area with a highest peak of $7546 \mathrm{~m}$. The ELA is between 5300 and $5500 \mathrm{~m}$. In July and August 2002, samples of newly deposited snow and melting residual snow were collected between 4900 and $5500 \mathrm{~m}$. 


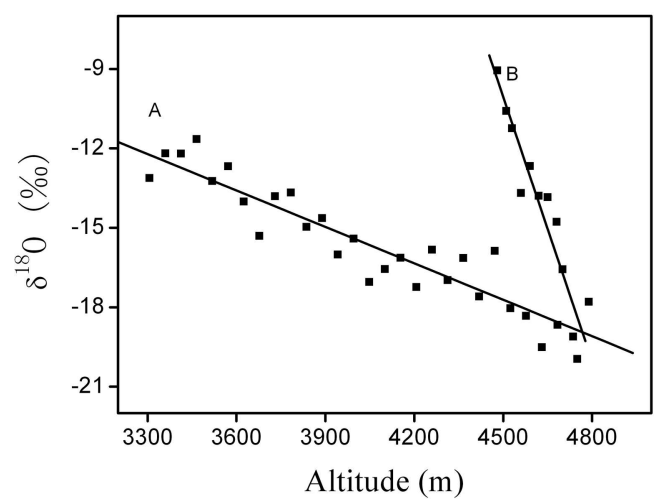

Fig. 3. Altitudinal variations of $\delta^{18} \mathrm{O}$ values of glacier meltwater at Yulong mountain, November 2002, (A) and of supraglacial meltwater below the equilibrium line on BG1, July 2000 (B).

Samples were immediately transferred to pre-cleaned polyethylene bottles. The $\delta^{18} \mathrm{O}$ values of the samples were determined at the Laboratory of Ice Core and Cold Regions Environment, Chinese Academy of Sciences, using MAT-252 and DeltaPlus mass spectrometers, with a precision of $\pm 0.2 \%$.

\section{RESULTS}

The $\delta^{18} \mathrm{O}$ values of samples of newly deposited snow collected between 3200 and $4900 \mathrm{ma}$ a.s.l. on Yulong mountain on 26 November 2002 decreased with increasing altitude (Fig. 2a). This snow was precipitated by the winter monsoon, and little melting occurred at the time of collection as temperatures generally were below $0^{\circ} \mathrm{C}$. The mean $\delta^{18} \mathrm{O}$ value was $-10.56 \%$ (Table 1 ), and the altitudinal gradient $\left(-0.22 \%(100 \mathrm{~m})^{-1}\right.$ was within the usual range for precipitation, $-0.15 \% 0(100 \mathrm{~m})^{-1}$ to $-0.50 \%(100 \mathrm{~m})^{-1}$ (Clark and Fritz, 1997).

The altitudinal pattern of $\delta^{18} \mathrm{O}$ values of residual snow which had fallen in late October and early November, before the end of the summer monsoon, and was sampled on 15 November 2002, was more complex (Fig. 2b). Between 4000 and $4550 \mathrm{~m}$, the $\delta^{18} \mathrm{O}$ values decreased with increasing altitude, at $-0.60 \%\left(100 \mathrm{~m}^{-1}\right.$; the mean value was $-14.76 \%$. However, both above and below this zone, the altitudinal change in $\delta^{18} \mathrm{O}$ values was in the reverse direction: they increased with increasing altitude. From 3200 to $4000 \mathrm{~m}$, the gradient was $0.56 \%(100 \mathrm{~m})^{-1}$ and the mean $\delta^{18} \mathrm{O}$ value was $-15.38 \%$. Between 4550 and $4900 \mathrm{~m}$, the gradient was $0.44 \%(100 \mathrm{~m})^{-1}$ and the mean $\delta^{18} \mathrm{O}$ value was $-15.72 \%$. The overall mean $\delta^{18} \mathrm{O}$ value of the residual snow deposited during the summer monsoon $(-15.18 \%)$ was far lower than that of the snow deposited during the early stage of the winter monsoon (Table 1 ).

In July $2000, \delta^{18} \mathrm{O}$ values of the melting snowpack below $4800 \mathrm{~m}$ decreased sharply with increasing altitude, at $-1.11 \%(100 \mathrm{~m})^{-1}$. Above $4800 \mathrm{~m}$, however, they increased with altitude, at $1.73 \%\left(100 \mathrm{~m}^{-1}\right.$ (Fig. 2c).

$\delta^{18} \mathrm{O}$ values of meltwater samples collected on Yulong mountain in both winter and summer decreased with increasing altitude (Fig. 3), but with very different altitudinal gradients: $-0.49 \%(100 \mathrm{~m})^{-1}$ in winter and $-3.33 \% 0(100 \mathrm{~m})^{-1}$ in summer.

The $\delta^{18} \mathrm{O}$ values of recently deposited new snow collected in July 2002 at the western branch of UG1 tended

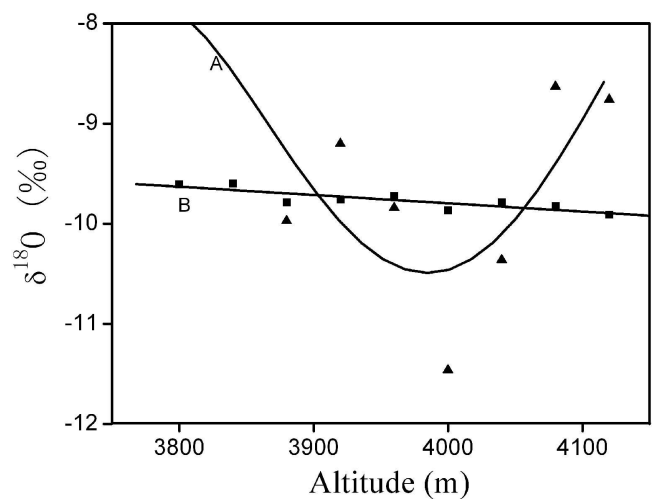

Fig. 4. Altitudinal variations of $\delta^{18} \mathrm{O}$ values of the melting residual snowpack on the eastern branch of UG1, August 2002, (A) and of new snow on the western branch of UG1, August 2002 (B).

to decrease slightly with increasing elevation, although the apparent differences were close to the precision of the analyses (Fig. 4b); the mean value was $-9.49 \%$. However, the $\delta^{18} \mathrm{O}$ values of older melting snow at the eastern branch of the glacier (mean value $-4.50 \%$ ) varied in a more complex manner, with a general trend of decreasing values as altitude increased from $3800 \mathrm{~m}$ to $4000 \mathrm{~m}$ contrasting with an increase in values above $4000 \mathrm{~m}$ (Fig. 4a).

The $\delta^{18} \mathrm{O}$ values of newly deposited snow collected at the Muztag mountain glacier in July 2002 were relatively high, with a mean value of $-5.47 \%$. The temperature on Muztag mountain, a non-monsoonal area, influences the isotopic composition of summer precipitation. The $\delta^{18} \mathrm{O}$ values decreased with increasing altitude (Fig. 5a), although the gradient $\left(-0.23 \%\left(100 \mathrm{~m}^{-1}\right)\right.$ over the $600 \mathrm{~m}$ altitudinal range within which samples were collected was relatively low. The $\delta^{18} \mathrm{O}$ value $(-14.68 \%$ o $)$ of the glacier ice at $4600 \mathrm{~m}$ and the mean $\delta^{18} \mathrm{O}$ value of supraglacial meltwater collected between 4300 and $4600 \mathrm{~m}(-13.53 \%$ ) were far lower than the $\delta^{18} \mathrm{O}$ value of recently deposited snow.

The $\delta^{18} \mathrm{O}$ values of the 12 samples of recently deposited snow collected between 5400 and $6700 \mathrm{~m}$ on Samdain Kangsang mountain in July 2003 were low, with a mean value of $-19.83 \%$. The values tended to be lower at lower altitudes (Fig. 5b).

\section{DISCUSSION}

The isotopic composition of snow is a result of spatial and temporal variations of the depositional environment. However, the isotopic composition of a snow cover is also the

Table 1. Maximum, mean and minimum $\delta^{18} \mathrm{O}$ values of samples of new snow, old (residual) snow and meltwater collected at Yulong mountain in November 2002, and $\delta^{18} \mathrm{O}$ values of meltwater samples collected in July 2000. $n$ is the number of samples

\begin{tabular}{lcccc}
\hline & New snow & Old snow & $\begin{array}{c}\text { Meltwater, } \\
\text { Nov. 2002 }\end{array}$ & $\begin{array}{c}\text { Meltwater, } \\
\text { July 2000 }\end{array}$ \\
\hline Maximum & -8.25 & -12.92 & -10.96 & -10.59 \\
Mean & -10.56 & -15.22 & -14.96 & -14.12 \\
Minimum & -13.28 & -18.25 & -18.82 & -19.95 \\
$n$ & 35 & 35 & 29 & 10 \\
\hline
\end{tabular}




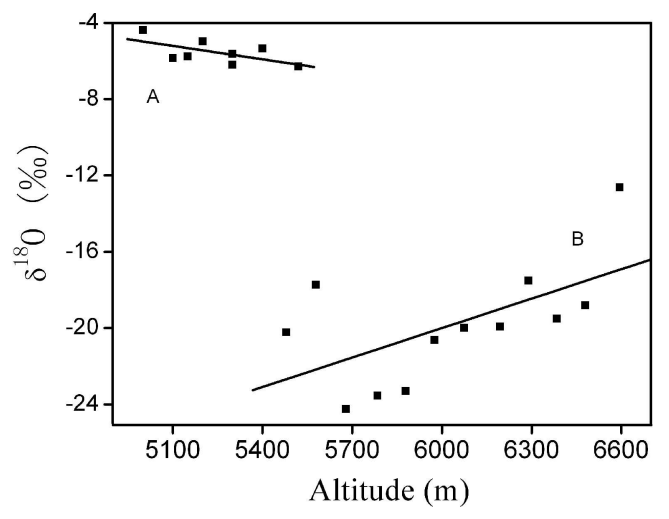

Fig. 5. Altitudinal variations of $\delta^{18} \mathrm{O}$ values of new snow on Muztag glacier, July 2002, (A) and of new snow on Samdain Kangsang mountain, July 2003 (B).

result of both depositional and post-depositional processes (which are related to spatial and temporal variations). Deposition-related processes include moisture source area, air-mass trajectory between the source and site of precipitation, temperature, altitude and precipitation amount. Accumulated snow is subject to post-depositional processes including evaporation (especially at high elevation in clearsky conditions), sublimation, ablation, meltwater percolation and drifting (Ambach and others, 1968; Niewodniczaéski and others, 1981). Melting increases the $\delta^{18} \mathrm{O}$ values of the near-surface snow (Cooper and others, 1993; Nikolayev and Mikhalev, 1995), and the percolating water is heavy-isotope enriched (Theakstone, 2003). Evaporation and sublimation also result in ${ }^{18} \mathrm{O}$ enrichment of the surface snow, as there is a progressive loss of mass (Stichler and others, 2001). Drifting, which is particularly effective in dry snow (Schlosser, 1999) and tends to move snow from higher to lower altitudes, can be effective in removing the lighter isotopes. At high-altitude sites in Alaska, USA, and Argentina, altitudinal variations of $\delta^{18} \mathrm{O}$ values of snow reflected the influence of a multi-layered atmosphere during precipitation events: in the Saint Elias Mountains, Alaska, this structure is related to synoptic-scale polar-front cyclones, which contain moisture from two quite different air masses (Holdsworth and Krouse, 2002). Understanding of the above questions will help glaciologists and hydrologists to interpret the isotopic and climatic information in ice cores and glacial runoff in different areas.

\section{Yulong mountain (temperate glacier)}

The mean $\delta^{18} \mathrm{O}$ value of the new snow deposited on Yulong mountain by the winter monsoon in November 2002 (Table 1) was far higher than that of the older residual snow which had accumulated during the summer monsoon. The decrease in $\delta^{18} \mathrm{O}$ values of the new snow with increasing altitude (Fig. 2a) was an evident 'temperature effect'. The more complex altitudinal pattern of $\delta^{18} \mathrm{O}$ values of the old (residual) snow (Fig. 2b) may reflect both its precipitation history and subsequent changes. Precipitation on Yulong mountain is more frequent above approximately $3900 \mathrm{~m}$ than at lower altitudes, and the residual snow sampled between 3200 and $4900 \mathrm{~m}$ was not deposited during a single event. The snow above $4000 \mathrm{~m}$ was deposited only a few days before samples were collected, after the summer monsoon had ended. Between
4000 and $4550 \mathrm{~m}$, the altitudinal gradient of the $\delta^{18} \mathrm{O}$ values (Fig. 2b) probably reflects the decrease in temperature with altitude during snow precipitation. However, the onset of winter at Yulong mountain in November 2002 was accompanied by sunny weather, and the clear-sky conditions must have caused evaporation by solar radiation in the highest parts of the snowpack. This process causes heavy-isotope enrichment (Gonfiantini, 1986), which is likely to have caused the reverse altitude effect of the $\delta^{18} \mathrm{O}$ values above $4550 \mathrm{~m}$ (Fig. 2b). However, the altitudinal variation of $\delta^{18} \mathrm{O}$ values in the old snow between 3200 and $4000 \mathrm{~m}$ requires a different interpretation. This snow was deposited during the summer monsoon and was melting when samples were collected in mid-November. Ablation increased with decreasing altitude and there was a corresponding increase in the amount of meltwater entering the snowpack. The snow at the lowest altitudes at which samples were collected may have contained meltwater which had originated at higher altitudes and was moving through the pack.

The variations of snowpack $\delta^{18} \mathrm{O}$ values on BG1 in July 2000 (Fig. 2c) reflect the summer climate. Below the ELA $(4800 \mathrm{~m})$, the intense ablation results in a rapid decrease in snow-cover thickness, and water passes rapidly through the thinning pack, leaving it progressively more enriched in ${ }^{18} \mathrm{O}$. While strong winds and air temperatures above $0^{\circ} \mathrm{C}$ also cause melting above the equilibrium line, the melt rate decreases with increasing altitude, and the meltwater passes more slowly through the snowpack. The reverse altitude effect exhibited by $\delta^{18} \mathrm{O}$ values above $4800 \mathrm{~m}$ may result from the increase in water content of the snowpack with decreasing altitude.

The $\delta^{18} \mathrm{O}$ values of meltwater at BG1 increased with decreasing altitude, but the rate of decrease differed markedly between summer and winter (Fig. 3). This can be explained by the climatic difference between winter and summer. In winter, Yulong mountain is affected by the Mongolia high pressure and is dominated by the winter monsoon, resulting in dry weather and low precipitation. Melting is relatively slight. In summer, however, when the summer monsoon is dominant, the higher temperatures cause much melting of snow and ice. Meltwater flowing over the surface is subject to evaporation and, with increasing distance of flow and decreasing altitude, the effects of evaporation become progressively more pronounced. The resultant 'flow-process effect' on $\delta^{18} \mathrm{O}$ values of the meltwater (Fig. 3b) is much more intense than it is in winter (Fig. 3a), when the temperature, evaporation and isotopic fractionation are much lower and less intense.

\section{Ürümqi glacier No. 1 (subpolar glacier)}

$<\cup G 1$, located in a region with an arid climate, receives less precipitation than does Yulong mountain, and the lower summer temperatures result in less ablation and less supraglacial meltwater than at BG1. Hou and others (1999) reported a significant relationship between temperature and the $\delta^{18} \mathrm{O}$ values of precipitation at the head of the Ürümqi river. About $90 \%$ of the precipitation fell during the summer half of the year, when $\delta^{18} \mathrm{O}$ values were high, with means of $-7.15 \%$ in July and August 1981 and $-7.13 \%$ in July and August 1995. The $\delta^{18} \mathrm{O}$ values of the snow which falls at UG1 in late winter are low, and early summer melting of this snow is followed by refreezing within the pack. Subsequent melting may cause runoff of older snow 
which was deposited in warmer conditions in early winter and has higher $\delta^{18} \mathrm{O}$ values. Hou and others (1999) noted that $\delta^{18} \mathrm{O}$ values of the residual pack remained low. In August 2002, $\delta^{18} \mathrm{O}$ values of new snow at the western branch of UG1 were high and displayed no significant altitude effect or temperature effect (Fig. 4). This may have been due to conditions at the time of precipitation. Changes in the direction of air movement during a storm, drifting of snow between altitudinal zones and snowfall from cloud covering the whole of the glacier in the sampled altitudinal zone may eliminate the altitude effect (Niewodniczaéski and others, 1981). The residual snow at the eastern branch of UG1 was probably deposited in different precipitation events and had been subject to differing degrees of melting and post-depositional modification.

\section{Muztag mountain (polar glacier)}

The $\delta^{18} \mathrm{O}$ values of newly deposited snow at Muztag glacier were high, and within the $520 \mathrm{~m}$ of elevation sampled in July 2002 the range was small (Fig. 5). The absence of a pronounced altitude effect or temperature effect in this continental climate region (Fig. 5) may be the result of atmospheric conditions above $5000 \mathrm{~m}$. The $\delta^{18} \mathrm{O}$ value $(-14.68 \%)$ of the glacier ice at $4600 \mathrm{~m}$ was far lower than that of the recently deposited snow, reflecting its formation at a much lower temperature than in July 2002: ice now exposed at the glacier surface at $4600 \mathrm{~m}$, some $700-900 \mathrm{~m}$ below the ELA, is likely to have been formed from snow that accumulated at a much higher site. The $\delta^{18} \mathrm{O}$ values of the meltwater at $4600 \mathrm{~m}$ indicate that it was formed in part from winter-deposited snow with a higher ${ }^{18} \mathrm{O}$ content than the glacier ice at that altitude (Fig. 5). The contribution of melting glacier ice to the meltwater sampled on Muztag glacier was significant, and the decrease in $\delta^{18} \mathrm{O}$ values of supraglacial meltwater with decreasing elevation reflects the increasing role of glacier ice in meltwater generation. The contrast with the pattern at Yulong mountain reflects the different intensities of ablation of snow and ice in the areas with temperate and polar glaciers.

\section{Samdain Kangsang mountain (subpolar glacier)}

The summer precipitation at Samdain Kangsang mountain in the Nyainqentanglha Shan is associated with the summer monsoon. The low $\delta^{18} \mathrm{O}$ values (Fig. 5) suggest there is a marked precipitation amount effect during the long passage of the southwest/India monsoon from the distant moisture source. At Lha-jung meteorological station $\left(27^{\circ} 54^{\prime} \mathrm{N}\right.$; 4420 ma.s.I.) on the southern slopes of the Himalaya, precipitation during the summer monsoon season of 1975 was strongly depleted of the heavy isotope, indicating that the amount effect is the dominant control on the isotopic composition of precipitation during this part of the year (Wushiki, 1977). The altitudinal variation of $\delta^{18} \mathrm{O}$ values in the new snow above 6000 m on Samdain Kangsang mountain may be related to evaporation. At these altitudes, the water-vapor and aerosol content of the air is small, and absorption and dispersion of solar radiation is slight compared with the situation at lower altitude. The high radiation flux causes much evaporation from the snow surface, leading to ${ }^{18} \mathrm{O}$ enrichment and a reverse altitude effect. This process cannot account for the somewhat similar pattern of $\delta^{18} \mathrm{O}$ values in the lower alpine area of Yulong mountain, where the altitudinal range of sampling was only $300 \mathrm{~m}$ and the differences in evaporation intensity from the surface snow are slight. On Samdain Kangsang mountain, the water content of new snow above $6000 \mathrm{~m}$ is low, as there is very little ablation. However, an increase in ablation with decreasing altitude towards $5500 \mathrm{~m}$ may result in a slight increase in water content, with a consequent increase in $\delta^{18} \mathrm{O}$ values.

\section{CONCLUSIONS}

The following conclusions can be drawn from the above analysis and discussion.

1. Stable isotopes in the snowpack in mountain regions are useful tracers of atmospheric conditions, reflecting both the temporal and the spatial variations of the local climate and isotopic fractionation during the phase changes between solid, liquid and vapor. Post-depositional processes, including those associated with meltwater flow, lead to additional stable-isotope changes. Stableisotope data shed light on the differences in atmospheric precipitation (i.e. sources and amounts) and the depositional and post-depositional processes associated with snow and ice conditions in both temperate- and polar-glacier areas.

2. Altitudinal patterns of $\delta^{18} \mathrm{O}$ values which are present in summer in recently deposited snow differ between the temperate-glacier area, influenced by the monsoon, and the polar-glacier area which is not associated with the monsoon (Fig. 1). The $\delta^{18} \mathrm{O}$ values of new snow in the temperate-glacier area tend to decrease with increasing altitude in winter, the altitude effect being related to precipitation from local sources. In the polar-glacier area, snowfall from continental air masses in summer may produce a reverse altitude effect.

3. Principally because of post-depositional processes, the spatial pattern of $\delta^{18} \mathrm{O}$ variations in older melting snow is more complex, varying in different altitudinal zones, partly in relation to solar radiation and evaporation intensities, the rate or degree of melting and the water content of the snow. Prolongation of the period of ablation and evaporation increases the $\delta^{18} \mathrm{O}$ value of the residual snow, which therefore reflects local climate and weather conditions.

4. The $\delta^{18} \mathrm{O}$ values of meltwater formed from snow and ice tend to increase with decreasing altitude and increasing distance of flow in both temperate-glacier and polarglacier regions. This results from the increasing contact of the flowing meltwater with meltwater in the residual snow, which is less depleted of ${ }^{18} \mathrm{O}$. The altitudinal gradient of the $\delta^{18} \mathrm{O}$ values is higher in summer than in winter, because of the higher temperature and greater evaporation.

5. The difference between the isotopic composition of newly deposited snow and that of melting residual snow is greater in the temperate-glacier area than in the polarglacier area, because of greater ablation and meltwater percolation into the snow cover. Isotopic fractionation during the phase changes between solid (snow/ice) and liquid (meltwater) is more pronounced in the temperateglacier area than in the polar-glacier area. 


\section{ACKNOWLEDGEMENTS}

This work was supported by grants from the National Natural Science Foundation of China (90511007, 40501014 and 90302006), funding from CAREE, Chinese Academy of Sciences (2004102), the Hundred Talents Program of Chinese Academy of Sciences (2004401) and the project for Outstanding Young Scientists of the National Natural Science Foundation of China (40121101).

\section{REFERENCES}

Ambach, W., W. Dansgaard, H. Eisner and J. Møller. 1968. The altitude effect on the isotopic composition of precipitation and glacier ice in the Alps. Tellus, 20(4), 595-600.

Bradley, R.S., M. Vuille, D. Hardy and L.G. Thompson. 2003. Low latitude ice cores record Pacific sea surface temperatures. Geophys. Res. Lett., 30(4), 1174. (10.1029/2002GL016546.)

Clark, I.D. and P. Fritz. 1997. Environmental isotopes in hydrogeology. New York, CRC Lewis.

Cooper, L.W., C. Solis, D.L. Kane and L.D. Hinzman. 1993. Application of oxygen-18 tracer techniques to Arctic hydrological processes. Arct. Alp. Res., 25(3), 247-255.

Dansgaard, W. 1964. Stable isotopes in precipitation. Tellus, 16(4), 436-468.

Gonfiantini, R. 1986. Environmental isotopes in lake studies. In Fritz, P. and J.C. Fontes, eds. Handbook of environmental isotope geochemistry. Vol. 1. The terrestrial environment. Amsterdam, Elsevier Scientific, 113-168.

Grootes, P.M., M. Stuiver, L.G. Thompson and E. MosleyThompson. 1989. Oxygen isotope changes in tropical ice, Quelccaya, Peru. J. Geophys. Res., 94(D1), 1187-1194.

He, Y. and W.H. Theakstone. 1994. Climatic influence on the composition of snow cover at Austre Okstindbreen, Norway, 1989 and 1990. Ann. Glaciol., 19, 1-6.

He, Y., T. Yao, G. Cheng and M. Yang. 2001a. Climatic records in a firn core from an Alpine temperate glacier on Mt. Yulong, southeastern part of the Tibetan Plateau. Episodes, 24(1), 13-18.

He, Y., W.H. Theakstone, Y. Shi and T. Yao. 2001b. The isotopic record at an alpine glacier and its implications for local climatic changes and isotopic homogenization processes. J. Glaciol., 47(156), 147-151.

Holdsworth, G. and H.R. Krouse. 2002. Altitudinal variation of the stable isotopes of snow in regions of high relief. J. Glaciol., 48(160), 31-41.

Hou, S. and 6 others. 1999. Climatological significance of $\delta^{18} \mathrm{O}$ in precipitation and ice cores: a case study at the head of the Ürümqi river, Tien Shan, China. J. Glaciol., 45(151), 517-523.

Ingraham, N.L. 1998. Isotopic variations in precipitation. In Kendall, C. and J.J. McDonnell, eds. Isotope tracers in catchment hydrology. Amsterdam, Elsevier Science BV, 87-118.

Johnson, K.R. and B.L. Ingram. 2004. Spatial and temporal variability in the stable isotope systematics of modern precipitation in China: implications for paleoclimate reconstructions. Earth Planet. Sci. Lett., 220(3-4), 365-377.

Moser, H. and W. Stichler. 1980. Environmental isotopes in ice and snow. In Fritz, P. and J.C. Fonte, eds. Handbook of environmental isotope geochemistry. Amsterdam, Elsevier Publishing Co., 141-178.

Niewodniczaéski, J., J. Grabczak, L. Baranski and J. Rzepka. 1981. The altitude effect on the isotopic composition of snow in high mountains. J. Glaciol., 27(95), 99-111.
Nikolayev, V.I. and D.V. Mikhalev. 1995. An oxygen-isotope paleothermometer from ice in Siberian permafrost. Quat. Res., 43, 14-21.

Raben, P. and W.H. Theakstone. 1998. Changes of ionic and oxygen isotopic composition of the snowpack at the glacier Austre Okstindbreen, Norway, 1995. Nord. Hydrol., 29(1), 1-20.

Schlosser, E. 1999. Effects of seasonal variability of accumulation on yearly mean $\delta^{18} \mathrm{O}$ values in Antarctic snow. J. Glaciol., 45(151), 463-468.

Shi, Y. and Z. Xie. 1964. Basic characteristics of the existing glaciers in China. Acta Geographica Sinica, 30(3), 183-208. [In Chinese with Russian abstract.]

Shi, Y., M. Huang and B. Ren. 1988. An introduction to the glaciers in China. Beijing, Science Press. [In chinese.]

Shi, Y., M. Huang, T. Yao and Y.X. Deng, eds. 2000. Glaciers and their environments in China: the present, past and future. Beijing, Science Press. [In Chinese.]

Stichler, W., U. Schotterer, K. Fröhlich, P. Ginot, C. Kull and H.W. Gäggeler. 2001. The influence of sublimation on stable isotope records recovered from high altitude glaciers in the tropical Andes. J. Geophys. Res., 106(D19), 22,613-22,620.

Su, Z. and J. Li, eds. 1996. Glaciers in Hengduanshan Range. Beijing, Science Press. [In Chinese with English summary.]

Theakstone, W.H. 1988. Temporal variations of isotopic composition of glacier-river water during summer: observations at Austre Okstindbreen, Okstindan, Norway. J. Glaciol., 34(118), 309-317.

Theakstone, W.H. 2003. Oxygen isotopes in glacier-river water, Austre Okstindbreen, Okstindan, Norway. J. Glaciol., 49(165), 282-298.

Theakstone, W.H. and N.T. Knudsen. 1989. Temporal changes of glacier hydrological systems indicated by isotopic and related observations at Austre Okstindbreen, Okstindan, Norway, 197687. Ann. Glaciol., 13, 252-256.

Theakstone, W.H. and N.T. Knudsen. 1996. Oxygen isotope and ionic concentrations in glacier river water: multi-year observations in the Austre Okstindbreen basin, Norway. Nord. Hydrol., 27(2), 101-116.

Thompson, L.G. and 11 others. 1998. A 25,000-year tropical climate history from Bolivian ice cores. Science, 282(5395), 1858-1864.

Tian, L., T.D. Yao and J.C. Pu. 1997. Characteristics of $\delta^{18} \mathrm{O}$ in summer precipitation at Lhasa. J. Glaciol. Geocryol., 19(4), 295-301. [In Chinese with English summary.]

Tian, L.D., T.D. Yao, A. Numaguti and W. Sun. 2001. Stable isotope variations in monsoon precipitation on the Tibetan Plateau. J. Meteorol. Soc. Jpn, 79(5), 959-966.

Tian, L.D., T.D. Yao and P.F. Schuste. 2003. Oxygen-18 concentrations in recent precipitation and ice cores on the Tibetan Plateau. J. Geophys. Res., 108(D9), 4293-4302. (10.1029/ 2002JD002173.)

Wagenbach, D. 1989. Environmental records in alpine glaciers. In Oeschger, H. and C.C. Langway, Jr, eds. The environmental record in glaciers and ice sheets. Chichester, etc., John Wiley and Sons, 69-83.

Wushiki, H. 1977. Deuterium content in the Himalayan precipitation at Khumbu District, observed in 1974/1975. J. Jpn. Soc. Snow and lce, Seppyo, 39, 50-56.

Zhang, X.P. and T.D. Yao. 1995. The relationship between the weather system influencing Tibet Plateau and the oxygen isotope of precipitation. J. Glaciol. Geocryol., 17, 125-131. [In Chinese with English summary.]

Zhang, X.P., M. Nakawo and K. Fujita. 2001. The variation of precipitation $\delta^{18} \mathrm{O}$ in Langtang Valley, Himalayas. Science in China, D31, 206-213. 